\title{
STUDENTS' KNOWLEDGE AND ATTITUDES TOWARDS INCLUSION IN COLLEGE
}

\author{
Laurensia Aptik Evanjeli \\ Sanata Dharma University, Indonesia \\ e-mail: laura.aptik@usd.ac.id
}

\begin{abstract}
Students' knowledge and attitudes towards individuals with special needs contribute to the realization of inclusion. This study aims to describe the graduate students' knowledge and attitudes towards graduate students with special needs. The number of participants in this study was $130(37.14 \%$ response rate) with an age range of 18-30 years. Correlation analysis, $t$-test analysis, and ANOVA was conducted to determine the relationship between student knowledge and their attitudes, and comparison of the demographic data. The results showed that there was a positive relationship between knowledge and attitudes towards inclusion but the correlation between knowledge and attitudes towards inclusion tended to be weak. The low correlation coefficient between knowledge and attitudes indicates that knowledge about disabilities is not the main factor determining student attitudes towards inclusion. The experience of interacting with individuals with special needs did not significantly contribute to knowledge and attitudes towards inclusion. The reported interactions with individuals with special needs are in the form of very close and close relationships such as relation with family members, close enough relationships such as relation with colleagues or staff, and acquaintances such as relation with neighbors.
\end{abstract}

\section{Keywords: knowledge, attitudes, inclusion in college.}

\section{PENGETAHUAN DAN SIKAP MAHASISWA TERHADAP INKLUSIVITAS INDIVIDU DI PERGURUAN TINGGI}

\begin{abstract}
Abstrak: Pengetahuan dan sikap penerimaan mahasiswa terhadap individu berkebutuhan khusus berkontribusi pada terwujudnya inklusivitas. Penelitian ini bertujuan untuk mendeskripsikan pengetahuan dan sikap mahasiswa terhadap mahasiswa berkebutuhan khusus. Partisipan penelitian ini berjumlah 130 orang (37,14\% tingkat partisipasi) dengan rentang usia 18-30 tahun. Analisis korelasi, $t$-test, dan ANOVA dilakukan untuk mengetahui hubungan antara pengetahuan dan sikap mahasiswa, serta membanding data demografi. Hasil menunjukkan bahwa terdapat hubungan yang positif antara pengetahuan dan sikap terhadap inklusi namun korelasi antara pengetahuan dan sikap terhadap inklusi cenderung lemah. Besar koefisien korelasi antara pengetahuan dan sikap yang rendah mengindikasikan bahwa pengetahuan tentang disabilitas bukan menjadi faktor utama yang menentukan sikap mahasiswa terhadap inklusifitas. Pengalaman berinteraksi dengan individu berkebutuhan khusus tidak berkontribusi secara signifikan pada pengetahuan dan sikap terhadap inklusifitas. Bentuk interaksi dengan individu berkebutuhan khusus yang dilaporkan berupa relasi yang sangat dekat dan dekat seperti anggota keluarga, cukup dekat seperti kolega atau staf, serta kenalan seperti tetangga.
\end{abstract}

Kata Kunci: pengetahuan, sikap, inklusi di perguruan tinggi.

\section{INTRODUCTION}

Inclusive education is expected to be implemented in every level of education. The Indonesian government is increasingly encouraging educational institutions to provide inclusive education, including universities. The Ministry of Research, Technology and Higher Education (Kemenristekdikti) issued the Regulation of the Minister of Research, Technology and Higher Education of the
Republic of Indonesia number 46 of 2017 that concerns special education and special service education in higher education or college. The regulation expects the universities to facilitate students with special needs with access to education, followed by services according to their needs (Permenristekdikti, 2017).

To realize an inclusive higher education, universities need to prepare facilities and infrastructure, as well as human resources who 
are ready to accept students with special needs. The knowledge and attitudes of lecturers, education staff, and students towards students with special needs are important factors for the sustainability of inclusion in higher education. The knowledge of the characteristics of special needs, as well as assistance or educational services following the needs of students, must be possessed by lecturers and educational staff to serve students with special needs according to their needs. Such knowledge must necessarily be accompanied by the acceptance of students with special needs.

Research conducted by Burmeister (2014) shows that participants generally know about individuals with special needs (75\%) and accept individuals with special needs by having the willingness to make friends with individuals with special needs (strongly agree $14 \%$ and agree $46 \%)(n=308)$. The willingness to make friends with individuals with special needs shows that in general there is acceptance of individuals who have different characteristics from people in general. Meyer, Myers, Walmsley, \& Laux (2012) also report that students without special needs have a neutral or positive perception towards the academic services for students with special needs, especially the students with ADHD and learning difficulties $(n=928)$. Related to the academic services for students with special needs, more than a third of the research participants had low awareness of the mentoring services for students with special needs. Students understand that students with special needs need additional classes compared to other students, but academic assistance facilities are considered unfair. The results of this study indicate that there are variations in student attitudes towards services for students with special needs, there are both acceptable and not acceptable things about it.

Alqarni, Algethami, Alsolmi, \& Adhabi (2019) explain that 1) some students have knowledge about disabilities but not all students have good knowledge about disabilities in general; 2) students generally have a positive attitude towards the inclusion that involves students with special needs; 3 ) there is a positive correlation between knowledge and attitudes towards inclusion, although it is not significant; and 4) there is no significant difference based on sex on knowledge, while in terms of attitudes, women show more positive attitude than men (n $=166$ ). The existence of proper knowledge about the concept of inclusion fosters the formation of a culture of inclusion in society as well as in institutions and it provides services that fit the needs of each individual.

The knowledge of inclusion should be owned by all university members, including lecturers and education staff. A survey was given to students and faculty members (including postgraduate students) with a total of 881 students while the faculty members and postgraduate students were 2,056. One-third of the participants said that the lecturer did not explain the existence of facilities for students with special needs, either orally or through the syllabus. This statement is supported by the data that half of the faculty members and half of the S2 students stated that they did not deliver the information about the availability of the disability service policy and chose to wait for students with special needs to contact the faculty (Bruder \& Mogro-Wilson, 2014).

The knowledge about individuals with special needs has to be supported by the realization of a positive attitude to create an inclusive community. Attitudes can be categorized into cognitive, affective, and behavior (Meyers \& Lester, 2016). Attitudes from a cognitive point of view describe the people's perspective of special needs as something annoying compared to the context in general which can have an impact on the quality of life (Vilchinsky \& Werner in Meyers \& Lester, 2016). In terms of affection, negative emotions that often arise against individuals with disabilities are low empathy, disgust, and anger or aggression. Regular students see themselves as superior compared to students with special needs. The behavior shown is in the form of avoiding, leaving space, or talking about individuals with special needs in their hopes (Brandes \& Crowson, 2009; Meyers \& Lester, 2016).

A positive attitude is shown by the preservice students in Pune, India to involve students who need modification mentoring from an academic perspective (such as students who have cognitive delays). Further positive attitudes are also shown to involve students who need social and physical assistance. Less supportive attitudes are shown to engage the students with disruptive behavior and require behavioral assistance, such 
as students who show verbal aggression. While the measurement of attention to implementing inclusive education, participants $(n=478)$, had a moderate level of concern for implementing inclusive learning in the classroom (Sharma, Moore, \& Sonawane, 2009).

In implementing inclusion in education, the obstacles that hinder the implementation of inclusion need to be known so that those obstacles can be overcome. The obstacles experienced by the students with special needs in finding or utilizing support services in higher education include (a) identity problems, (b) the desire to avoid negative reactions from the social environment, (c) lack of knowledge, (d) perceptions towards the quality and benefits of services provided, and (e) negative experiences with professors or lecturers. The desire to avoid negative reactions from the social environment is shown in the form of fear of negative behavior from other students because of special treatment aimed at students with special needs and a feeling of not wanting to get special treatment (Marshak, van Wieren, Ferrell, Swiss, \& Dugan, 2010).

This situation shows that there are indications that students do not fully understand individuals with special needs and there is the possibility of having a less accepting attitude towards students with special needs. Students who have sufficient knowledge about inclusion and disabilities, and are followed by a positive attitude can support the acceptance of students with special needs. Thus, the research aims to determine the knowledge and attitudes of students towards relevant inclusion or inclusion is carried out to support the realization of inclusive education in higher education.

\section{METHODS}

This study used a survey as a research method. The participants involved in this research were selected through the purposive sampling technique. Purposive sampling gives opportunities to the researcher to determine particular participants who correspond to research objectives (Best \& Kahn, 2006). The study participants were the students who took courses on individuals with special needs. The population of participants in this study was students of Sanata Dharma University who took the courses of Education for Children with Special Needs (PGSD), Individualized Education Program (BK), and Special Education (Psychology). The total population of participants in this study was 350 students, but 130 students (37.14\% response rate) were voluntarily willing to become participants.

Table 1 shows participant demographic data. There were 130 undergraduate students aged $18-30$ years $(M=20.70, S D=1.710)$ involved in this research. Some of Sanata Dharma University students are priests so it can be assumed that students aged 27 years and over are priests. The majority of participants were women at $79.2 \%(n=103)$. In terms of ethnicity, students were quite diverse with Javanese being the majority ethnic group at $58.5 \%(n=76)$ and the second-largest ethnic group is Batak at $14.6 \%$ $(n=19)$. Students also wrote mixed ethnicity because both parents came from two different ethnic groups, such as Chinese and Sundanese, Javanese and Chinese. In the question regarding the knowledge of acquaintances with disabilities, 113 students answered "yes". Participants were also asked about how close the participants were to individuals with special needs and there were four categories of answers: only acquaintances (for example neighbors, acquaintances of one place of worship) as much as $59.23 \%(n=77)$, quite close (e.g. colleagues, instructors, staff) as much as $10.77 \%(n=14)$, close (for example having cognition, friends) as much as $18.46 \%$ $(n=24)$, and very close (for example family members, husband/wife, children, biological relatives) as much as $11.54 \%(n=15)$.

\section{Table 1. Participant Demographic Data}

\begin{tabular}{llrc}
\hline & $\boldsymbol{n}$ & Percentage \\
\hline Gender & Female & 103 & 79.2 \\
Age & Male & 27 & 20.8 \\
& 18 & 2 & 1.5 \\
& 19 & 19 & 14.6 \\
20 & 49 & 37.7 \\
21 & 39 & 30.0 \\
22 & 8 & 6.2 \\
23 & 9 & 6.9 \\
27 & 2 & 1.5 \\
& 28 & 1 & .8 \\
Ethnic & 1 & .8 \\
& Jawa & 76 & 58.5 \\
& Batak & 19 & 14.6 \\
& Bali & 4 & 3.1 \\
& Mixed ethnic & 8 & 6.2 \\
NTT & 9 & 6.9 \\
& Dayak & 3 & 2.3 \\
Maluku & 3 & 2.3 \\
Sulawesi, East Timor & 7 & 5.4 \\
& Tionghoa & 1 & .8 \\
\hline
\end{tabular}


The procedure to collect the data was carried out online by distributing 350 questionnaires to students which were delivered through the lecturers. Students were informed to complete the questionnaire anonymously and they might not complete the survey if they did not wish to participate. The data collection process was carried out at the beginning of the even semester (March 2020). The number of questionnaires that were filled out from the participants was 130 .

The instrument used in the research of Alqarni et al. (2019) who also studied on knowledge about disabilities and student attitudes towards inclusion was also implemented in this study. The reliability of the instrument used Cronbach's alpha $(\alpha=.668)$. The instrument was in English and then adapted to Indonesian. The translation survey can be seen in Appendix 1. The questionnaire consisted of 20 questions: 10 questions for knowledge variables and 10 questions for attitude variables with five choices of answers ranging from strongly disagree to strongly agree (Likert scale). Descriptive statistics were used to analyze the background of the participants. Correlation analysis was used to determine the relationship between student knowledge and their attitudes. $t$-test analysis and ANOVA were conducted to compare the knowledge about disabilities and student attitudes towards inclusion regarding the demographic data.

\section{FINDINGS AND DISCUSSION Findings}

The number of participants $(n=130)$ is over one-third of the total population $(N=350)$. The range score of knowledge of disabilities is 21 with a mean of $37.92(S D=4.248)$ which means the data is represented a normal distribution. Attitudes towards inclusion have a range score of 23 with a mean of $35.01(S D=4.316)$. The variability of both data represents a normal distribution. The results of calculating skewness and kurtosis also show that the data distribution of both data is close to normal (Table 2). The normal distribution is also represented in the Kolmogorov-Smirnov calculation (Table 3).

The distribution of ethnicity in the knowledge of disabilities shows that Dayak ethnic participants have the highest variability although there are only three participants. The range score of Dayak ethnic participants is 13 . Dayak ethnic participants also show the highest variability in attitudes towards inclusion with a range score is 13 as well. The lowest variability in both knowledge of disabilities and attitudes towards inclusion is shown in Tionghoa ethnic participants since there is only one participant. The second-lowest variability in the knowledge of disabilities is shown in Maluku ethnic participants with a range score is 4 . Whereas, the second-lowest variability in attitudes towards inclusion is shown in Bali ethnic participants with a range score is 4 . The mean and standard deviation results can be seen in Table 4 .

Table 2. Descriptive Statistics

\begin{tabular}{|c|c|c|c|c|c|c|c|c|c|c|}
\hline & \multirow[b]{2}{*}{$N$} & \multirow[b]{2}{*}{ Min } & \multirow[b]{2}{*}{$\operatorname{Max}$} & \multirow[b]{2}{*}{ Mean } & \multirow[b]{2}{*}{$\begin{array}{c}\text { Std. } \\
\text { Deviation }\end{array}$} & \multirow{2}{*}{ Variance } & \multicolumn{2}{|c|}{ Skewness } & \multicolumn{2}{|c|}{ Kurtosis } \\
\hline & & & & & & & Statistic & $\begin{array}{c}\text { Std. } \\
\text { Error }\end{array}$ & Statistic & $\begin{array}{c}\text { Std. } \\
\text { Error }\end{array}$ \\
\hline $\begin{array}{l}\text { Knowledge of } \\
\text { disabilities }\end{array}$ & 130 & 28 & 49 & 37.92 & 4.248 & 18.047 & -.019 & .212 & -.039 & .422 \\
\hline $\begin{array}{l}\text { Attitudes towards } \\
\text { inclusion }\end{array}$ & 130 & 25 & 48 & 35.01 & 4.316 & 18.628 & .262 & .212 & .149 & .422 \\
\hline Valid $N$ (listwise) & 130 & & & & & & & & & \\
\hline
\end{tabular}

Table 3. Normality Test Result

\begin{tabular}{llcc}
\hline & & Knowledge of Disabilities & Attitudes towards Inclusion \\
\hline$N$ & & 130 & 130 \\
Normal parameters ${ }^{\mathrm{a}}$ & Mean & 37.920 & 35.010 \\
& Std. Deviation & 4.248 & 4.316 \\
Most extreme differences & Absolute & .080 & .094 \\
& Positive & .058 & .094 \\
& Negative & -.080 & -.054 \\
Kolmogorov-Smirnov $Z$ & & .911 & 1.068 \\
Asymp. Sig. (2-tailed) & & .378 & .204 \\
\hline
\end{tabular}

a. Test distribution is Normal. 
Table 4. Descriptive Statistics of Demographic Data

\begin{tabular}{|c|c|c|c|c|c|c|c|c|c|}
\hline & \multirow{2}{*}{$N$} & \multirow{2}{*}{ Mean } & \multirow{2}{*}{$\begin{array}{c}\text { Std. } \\
\text { Deviation }\end{array}$} & \multirow{2}{*}{$\begin{array}{c}\text { Std. } \\
\text { Error }\end{array}$} & \multicolumn{2}{|c|}{$\begin{array}{l}\text { 95\% Confidence } \\
\text { Interval for Mean }\end{array}$} & \multirow{2}{*}{ Min } & \multirow{2}{*}{ Max } \\
\hline & & & & & & $\begin{array}{l}\text { Lower } \\
\text { Bound }\end{array}$ & $\begin{array}{l}\text { Upper } \\
\text { Bound }\end{array}$ & & \\
\hline \multirow{10}{*}{$\begin{array}{l}\text { Knowledge of } \\
\text { disabilities }\end{array}$} & Java & 76 & 37.66 & 4.441 & .509 & 36.64 & 38.67 & 28 & 49 \\
\hline & Batak & 19 & 38.32 & 3.318 & .761 & 36.72 & 39.91 & 30 & 43 \\
\hline & Bali & 4 & 40.50 & 3.317 & 1.658 & 35.22 & 45.78 & 36 & 43 \\
\hline & Mixed ethnic & 8 & 35.25 & 2.816 & .996 & 32.90 & 37.60 & 30 & 39 \\
\hline & NTT & 9 & 38.44 & 4.927 & 1.642 & 34.66 & 42.23 & 31 & 46 \\
\hline & Dayak & 3 & 37.67 & 6.807 & 3.930 & 20.76 & 54.58 & 30 & 43 \\
\hline & Maluku & 3 & 38.33 & 2.309 & 1.333 & 32.60 & 44.07 & 37 & 41 \\
\hline & Sulawesi, East Timor & 7 & 40.86 & 4.100 & 1.550 & 37.07 & 44.65 & 36 & 46 \\
\hline & Tionghoa & 1 & 35.00 & - & - & - & - & 35 & 35 \\
\hline & Total & 130 & 37.92 & 4.248 & .373 & 37.18 & 38.65 & 28 & 49 \\
\hline \multirow{10}{*}{$\begin{array}{l}\text { Attitudes } \\
\text { towards } \\
\text { inclusion }\end{array}$} & Java & 76 & 35.18 & 4.235 & .486 & 34.22 & 36.15 & 25 & 48 \\
\hline & Batak & 19 & 34.68 & 3.092 & .709 & 33.19 & 36.17 & 30 & 41 \\
\hline & Bali & 4 & 38.50 & 1.732 & .866 & 35.74 & 41.26 & 36 & 40 \\
\hline & Mixed ethnic & 8 & 31.88 & 4.581 & 1.619 & 28.05 & 35.70 & 25 & 38 \\
\hline & NTT & 9 & 35.00 & 4.822 & 1.607 & 31.29 & 38.71 & 26 & 40 \\
\hline & Dayak & 3 & 36.33 & 6.506 & 3.756 & 20.17 & 52.50 & 30 & 43 \\
\hline & Maluku & 3 & 32.33 & 4.041 & 2.333 & 22.29 & 42.37 & 28 & 36 \\
\hline & Sulawesi, East Timor & 7 & 36.71 & 6.211 & 2.347 & 30.97 & 42.46 & 29 & 46 \\
\hline & Tionghoa & 1 & 31.00 & - & - & - & - & 31 & 31 \\
\hline & Total & 130 & 35.01 & 4.316 & .379 & 34.26 & 35.76 & 25 & 48 \\
\hline
\end{tabular}

One-way ANOVA analysis shows that there is no difference between knowledge of disabilities and attitudes towards inclusion based on ethnicity. Even though students from Javanese ethnicity are the highest participants, students from Sulawesi and East Timor have the highest average scores of knowledge of disabilities. The highest mean score of attitudes towards inclusion is shown by students who are from Bali.
The knowledge of disabilities and attitudes shows a linear relationship which is indicated by $F$ linearity $18.505(p<.05)$ (Table $5)$. The linear relationship is shown in deviation from linearity as well $(p>.05)$. The correlation analysis between knowledge of disabilities and attitudes towards inclusion shows a significant relationship $(p<.005)$ but both variables have a weak relationship $(r=.353)$ (Table 6$)$.

Table 5. Linearity Test Result

\begin{tabular}{|c|c|c|c|c|c|c|c|}
\hline & & & $\begin{array}{c}\text { Sum of } \\
\text { Squares }\end{array}$ & $d f$ & $\begin{array}{l}\text { Mean } \\
\text { Square }\end{array}$ & $F$ & Sig. \\
\hline \multirow{5}{*}{$\begin{array}{l}\text { Inklusi bagi } \\
\text { disabilitas* } \\
\text { pengetahuan } \\
\text { tentang } \\
\text { disabilitas }\end{array}$} & Between & (Combined) & 626.635 & 19 & 32.981 & 2.042 & .011 \\
\hline & groups & Linearity & 298.830 & 1 & 298.830 & 18.505 & .000 \\
\hline & & Deviation from linearity & 327.805 & 18 & 18.211 & 1.128 & .336 \\
\hline & Within groups & & 1776.357 & 110 & 16.149 & & \\
\hline & Total & & 2402.992 & 129 & & & \\
\hline
\end{tabular}

Table 6. Result of Correlation Analysis

\begin{tabular}{llcc}
\hline & & Knowledge of Disabilities & Attitudes towards Inclusion \\
\hline Knowledge of & Pearson correlation & 1 & $.353^{* *}$ \\
disabilities & Sig. (2-tailed) & & .000 \\
& $N$ & 130 & 130 \\
Attitudes towards & Pearson correlation & $.353^{* *}$ & 1 \\
inclusion & Sig. (2-tailed) & .000 & 130 \\
& $N$ & 130 & \\
\hline
\end{tabular}

\footnotetext{
**. Correlation is significant at the .01 level (2-tailed).
} 
The mean score of knowledge of disabilities among female students is not much different from the average score of male students, as well as the attitude towards inclusion (see Table 7). Male and female students have more or less the same knowledge of disabilities and attitudes towards inclusion. The calculation of the independent samples test shows that there is no difference between knowledge of disabilities and attitudes towards inclusion (see Table 8).

\section{Discussion}

\section{The relation between Knowledge of Disabilities and Attitudes towards Inclusion}

People with disabilities have faced discrimination for years. Many countries have been issued policies considering many aspects of life of people with disabilities, including education. There are barriers to include students with disabilities in mainstream schools, one among others is negative attitudes of typically developing students towards students with disabilities (Szumski, Smogorzewska, \& Grygiel, 2020). This study aims to know the knowledge of disabilities and attitudes towards inclusion of the students. The average score of knowledge of disabilities is 37.92 with a range of 28 to 49 and it indicates that students have sufficient knowledge about disabilities, but when it is viewed from the individual scores, it shows that some students have less knowledge about disabilities. In the items that inquired the knowledge of the meaning of disability, most participants knew the meaning of disability as a physical or mental disorder that can hinder one or more daily activities $(n=114)$. The response to this statement indicates that students have general knowledge about the meaning of disability so that it can be said that they are able to identify people with special needs around them.

In terms of attitudes towards inclusion, the average score of participants is 35.01 for the overall response item with a range score between 25 and 48. An item that states the integration between regular students and students with special needs can improve student learning experiences (both regular and special needs) get responses "agree" and "strongly agree" as many as 97 out of 130 participants. The data indicate that students have attitudes that support integration between regular students and students with special needs. Positive affect towards inclusion is closely related to the positive attitude of teachers (Navarro-Mateu, Franco-Ochoa, Valero-Moreno, \& Prado-Gascó, 2020). Therefore, the positive attitudes of this study participants indicated that they have a positive feeling towards inclusion.

Table 7. Descriptive Analysis of Knowledge and Attitudes Based on Gender

\begin{tabular}{llcccc}
\hline & Gender & $\boldsymbol{N}$ & Mean & Std. Deviation & $\begin{array}{c}\text { Std. Error } \\
\text { Mean }\end{array}$ \\
\hline Knowledge of disabilities & Female & 103 & 38.09 & 4.128 & .407 \\
& Male & 27 & 37.26 & 4.703 & .905 \\
Attitudes towards inclusion & Female & 103 & 35.02 & 4.341 & .428 \\
& Male & 27 & 34.96 & 4.301 & .828 \\
\hline
\end{tabular}

Table 8. Analysis of Differences between Knowledge and Attitudes Based on Gender

\begin{tabular}{|c|c|c|c|c|c|c|c|c|c|c|}
\hline & & \multicolumn{2}{|c|}{$\begin{array}{c}\text { Levene's Test } \\
\text { for Equality of } \\
\text { Variances } \\
\end{array}$} & \multicolumn{7}{|c|}{$t$-test for Equality of Means } \\
\hline & & \multirow[t]{2}{*}{$F$} & \multirow[t]{2}{*}{ Sig. } & \multirow[t]{2}{*}{$t$} & \multirow[t]{2}{*}{$d f$} & \multirow[t]{2}{*}{$\begin{array}{c}\text { Sig. } \\
\text { (2-tailed) }\end{array}$} & \multirow[t]{2}{*}{$\begin{array}{c}\text { Mean } \\
\text { Difference }\end{array}$} & \multirow[t]{2}{*}{$\begin{array}{l}\text { Std. Error } \\
\text { Difference }\end{array}$} & \multicolumn{2}{|c|}{$\begin{array}{l}\text { 95\% Confidence } \\
\text { Interval of the } \\
\text { Difference } \\
\end{array}$} \\
\hline & & & & & & & & & Lower & Upper \\
\hline \multirow[t]{2}{*}{$\begin{array}{l}\text { Knowledge of } \\
\text { disabilities }\end{array}$} & $\begin{array}{l}\text { Equal variances } \\
\text { assumed }\end{array}$ & .292 & .590 & .901 & 128 & .369 & .828 & .919 & -.991 & 2.647 \\
\hline & $\begin{array}{l}\text { Equal variances } \\
\text { not assumed }\end{array}$ & & & .834 & 37.174 & .409 & .828 & .992 & -1.182 & 2.839 \\
\hline \multirow{2}{*}{$\begin{array}{l}\text { Attitudes towards } \\
\text { inclusion }\end{array}$} & $\begin{array}{l}\text { Equal variances } \\
\text { assumed }\end{array}$ & .000 & .986 & .060 & 128 & .952 & .056 & .937 & -1.797 & 1.910 \\
\hline & $\begin{array}{l}\text { Equal variances } \\
\text { not assumed }\end{array}$ & & & .061 & 40.993 & .952 & .056 & .932 & -1.825 & 1.938 \\
\hline
\end{tabular}


The concept of attitudes can be explained in three components, namely cognitive, affective, and behavioral. The cognitive component in attitudes expressed an individual's knowledge about an object. The affective component is based on emotion or feeling towards the objective. The behavior in attitudes expressed an individual's tendency to behave considering the object in a certain way (de Boer, Pijl, \& Minnaert, 2012). The three components of attitudes indicated that an individual who have positive attitudes towards inclusion, an individual also has knowledge about inclusion, positive feeling towards inclusion, and positive act towards inclusive setting.

Supportive action is shown to involve the students with special needs as well as students with intellectual disabilities in the community in general. The presence of students with intellectual disabilities is said to be beneficial for both regular students and students with intellectual disabilities (Westling, Kelley, Cain, \& Prohn, 2013). Social support from peers and teaching staff in universities is one of the factors that contribute to the formation of selfadvocacy for students with special needs. If peers and teaching staff show social support, it can help students with special needs to succeed academically (Johnson, 2015).

Attitudes towards people with disabilities not only studied among students, teachers, and faculty staff, but also studied among society with a different culture (Westbrook, Legge, \& Pennay, 1993), adolescents (Bossaert, Colpin, Pijl, \& Petry, 2011), college students (Au \& Man, 2006; Chan, Lee, Yuen, \& Chan, 2002; Sahin \& Akyol, 2010), and employers (Burke, Bezyak, Fraser, Pete, Ditchman, \& Chan, 2013; Nota, Santilli, Ginevra, \& Soresi, 2014). Studies on this topic show that attitudes towards people with disabilities play an important role in creating an inclusive culture in all aspects of life. The negative attitudes towards people with disabilities had been emerged due to norms in the society and culture, and societies' expectations towards people's abilities (Livneh, 1982). However, there are many theoretical sources to explain the negative attitudes towards people with disabilities.

Correlation analysis is carried out to determine the relationship between knowledge and attitudes towards inclusion. Knowledge of disabilities and attitudes towards inclusion shows a significant and positive relationship $(p<.05)$ but the relationship between them is not strong $(r=.353)$. If students have good knowledge of disabilities, their attitudes towards inclusion also tend to be positive. The low correlation coefficient between knowledge and attitudes indicates that a lack of knowledge of disabilities does not mean that students do not have a positive attitude towards inclusion. The results of this study are consistent with the results of previous studies which show a correlation between knowledge and attitudes towards inclusion (Alqarni et al., 2019; Meyer et al., 2012).

An assessment of personal belief shows that faculty staffs at the individual level need to provide special services for students with special needs and support the institution to provide these special services. However, in terms of knowledge of disabilities, faculty staffs need to gain more knowledge about abilities and potentials, as well as the specific characteristics of the special needs category (Zhang, Landmark, Reber, Hsu, Kwok, \& Benz, 2010). Faculty staffs report that their knowledge is insufficient to identify the presence of students with special needs. Despite the lack of knowledge, faculty staffs have a strong belief that they are sensitive to the needs of students with special needs and know the reference place on campus that can facilitate students with special needs (Sniatecki, Perry, \& Snell, 2015).

This study result support previous study and it indicated that person who have knowledge of disabilities will also have positive attitudes towards inclusion. Otherwise, person who have positive attitudes towards inclusion or individual with special needs can trigger their curiosity about disabilities or special needs. Therefore, knowledge of disabilities and attitudes towards inclusion play important role in implementation of inclusive education.

Considering the demographic data of participants, we can compare the knowledge of disabilities and attitudes towards inclusion. In terms of gender and ethnicity, students have almost the same knowledge of disabilities and attitudes towards inclusion. The mean score, both knowledge of disabilities and attitudes towards inclusion, shows a similar magnitude and the results of the independent samples test (Table 6) also showed no difference based on gender or ethnicity. The knowledge of disabilities between 
men and women in previous studies also does not show any differences but there are differences in attitudes towards inclusion (Alqarni et al., 2019).

Indonesia has a great number of ethnicity where it is part of diversity to include in inclusive education. The Salamanca statement stated that schools should provide equal opportunities for all children apart from their disabilities, gifted abilities, ethnicities, and "marginalized" children as life on the street and remote area, life as working children, have a different language, and other marginalized areas (UNESCO, 1994). Participants of this study have various ethnicity, they represent eight ethnicities and one mixed ethnicity. Therefore, it represents the inclusivity in the university, also study participants.

The Indonesian various ethnicity resembles the United States various ethnicity. A study in international trends in inclusive education found that segregation still exists considering race groups, for example black and Hispanic, in contrast to white students. Despite various case across the states, it was approximately $7-10 \%$ fewer numbers of black students compared to white students regarding their opportunities to include in general education. Hispanic students have better opportunities to accept in general education in contrast to black students (Ferguson, 2008). This report suggested that there may need further concern regarding race or ethnicity to include in regular education.

A factor that may contribute to the knowledge of disabilities and attitudes towards inclusion is participation in courses or training that discuss disabilities and their educational support services. The participants of this research were the students who took a course on individuals with special needs. The data were collected after students attended the initial course meetings so that it could be assumed that students gained basic knowledge about individuals with special needs in general. Students who took inclusion training were reported to experience a significant increase in positive attitudes towards individuals with special needs compared to students who did not take inclusion training (Hunt \& Hunt, 2004; Tast, 2017). These results indicate that inclusion training or courses on individuals with special needs as in this study can help students have positive knowledge and attitudes towards individuals with special needs. If students can take courses on individuals with special needs or receive similar training, then the acceptance of individuals with special needs at the tertiary level will also increase.

Participants' knowledge of individuals with special needs can also be seen through the experiences of interacting with individuals with special needs. Most of the participants have acquaintances with special needs (59.23\%) which indicates that participants are able to recognize that the people around them have special needs. Among the participants who have very close and close relationships, such as blood relations, it is showed that some participants $(30 \%)$ have the opportunity to interact directly with individuals with special needs. Students who have family members or acquaintances with special needs show a more positive attitude than students who have not had interaction with individuals with special eeds (Tast, 2017; Westling et al., 2013). The experience of interacting with individuals with special needs is said to be one of the aspects that contribute to the acceptance of individuals with special needs in the community (Meyers \& Lester, 2016).

In contrast to previous studies, the results of this study indicate that there is no difference in attitudes towards inclusion between students who have ever interacted with individuals with special needs and students who have never interacted with individuals with special needs $(t=-1,445, p=.151)$. When it is viewed from the average attitudes towards inclusion based on interactions with individuals with special needs, students who have interaction experience have a lower average attitude $(M=34.80, S D=4.014)$ than students who have not had experience in interacting with individuals with special needs $(M=36.41, S D=5.917)$. These different findings indicate that there are specific factors that contribute to the attitudes of students who have experience in interacting with individuals with special needs that have not been revealed in this study.

One of the factors that contribute to the relationship between regular students and students with special needs is moral identity. Students who have a moral identity can improve their attitudes towards cognitive aspects towards individuals with special needs. Moral identity shapes students' motivation to have prosocial behavior so that students can show prosocial attitudes when situations expect prosocial 
behavior in dealing with individuals with special needs (Szumski et al., 2020). Positive attitudes towards inclusion and individuals with special needs do not appear to be limited to the knowledge possessed by individuals, but there are still other factors that contribute to the formation of positive attitudes.

\section{CONCLUSION}

This study aims to determine the knowledge and attitudes of students towards inclusion in higher education or college. The results shows a correlation between knowledge of disabilities and attitudes towards inclusion, but the correlation between them was not strong. A positive attitude towards inclusion or individuals with special needs is not only influenced by knowledge but there are other contributing factors such as moral identity. If it is described in more detail, attitudes have three aspects (cognitive, behavioral, and affective) that can be described separately to find out which aspects have the main contribution. This research is focused on demographic data and quantitative measurements so that it does not dig up qualitative data to be able to explore forms of interaction between students with special needs and regular students that contribute to the formation of positive attitudes towards inclusion and individuals with special needs.

\section{AKNOWLEDGEMENTS}

This research was carried out with the research funding from the LPPM Sanata Dharma University with a Study Center scheme (Pusat Studi Individu Berkebutuhan Khusus). The researchers are thankful for the grants and participation of all participants in this study.

\section{REFERENCES}

Alqarni, T., Algethami, R., Alsolmi,A., \& Adhabi, E. (2019). College students' knowledge and attitudes toward the inclusion of persons with disabilities in the university. Education, 9(1), 9-18. http://article.sapub. org/10.5923.j.edu.20190901.02.html.

Au, K. W., \& Man, D. W. K. (2006). Attitudes toward people with disabilities: A comparison between health care professionals and students. International Journal of Rehabilitation Research, 29(2),
155-160. https://doi.org/10.1097/01. mrr.0000210048.09668.ab.

Best, J. W., \& Kahn, J. V. (2006). Research in education $\left(10^{\text {th }}\right.$ ed). Boston, MA: Allyn and Bacon.

Bossaert, G., Colpin, H., Pijl, S. J., \& Petry, K. (2011). The attitudes of Belgian adolescents towards peers with disabilities. Research in Developmental Disabilities, 32(2), 504-509. https://doi.org/10.1016/j. ridd.2010.12.033.

Bruder, M. B., \& Mogro-Wilson, C. (2014). Student and faculty awareness and attitudes about students with disabilities. Review of Disability Studies, 6(2), 1-12. https://www.rdsjournal.org/index.php/ journal/article/view/169.

Burke, J., Bezyak, J., Fraser, R. T., Pete, J., Ditchman, N., \& Chan, F. (2013). Employers' attitudes towards hiring and retaining people with disabilities: A review of the literature. Australian Journal of Rehabilitation Counseling, 19(1), 21-38. https://doi.org/10.1017/jrc.2013.2.

Burmeister, A. (2014). Peer acceptance and the emotional well-being of disabled individuals. Perspectives, 6(1), 1-9. https://scholars.unh.edu/perspectives/ vol6/iss1/1.

Chan, C. C. H., Lee, T. M. C., Yuen, H.-K., \& Chan, F. (2002). Attitudes towards people with disabilities between Chinese rehabilitation and business students: An implication for practice. Rehabilitation Psychology, 47(3), 324-338. https://doi. org/10.1037/0090-5550.47.3.324.

de Boer, A., Pijl, S. J., \& Minnaert, A. (2012). Students' attitudes towards peers with disabilities: A review of the literature. International Journal of Disability, Development and Education, 59(4), 379-392. https://doi.org/10.1080/103491 2X.2012.723944.

Ferguson, D. L. (2008). International trends in inclusive education: The continuing challenge to teach each one and everyone. 
European Journal of Special Needs Education, 23(2), 109-120. https://doi. org/10.1080/08856250801946236.

Hunt, C. S., \& Hunt, B. (2004). Changing attitudes toward people with disabilities: Experimenting with an educational intervention. Journal of Managerial Issues, 16(2), 266-280. https://www.jstor. org/stable/40604458.

Johnson, J. I. M. (2015). The relationship between social support and self-advocacy in college students with disabilities (Doctoral dissertation, University of Denver). https://digitalcommons.du.edu/ etd $/ 1040$.

Livneh, H. (1982). On the origins of negative attitudes toward people with disabilities. Rehabilitation Literature, 43(11-12), 338-347. https://pubmed.ncbi.nlm.nih. gov/6219435/.

Marshak, L., van Wieren, T., Ferrell, D. R., Swiss, L., \& Dugan, C. (2009). Exploring barriers to college student use of disability services and accommodations. Journal of Postsecondary Education and Disability, 22(3), 151-165. https://www.ahead.org/ professional-resources/publications/jped/ archived-jped/jped-volume-22.

Permenristekdikti RI 2017 No. 46. Pendidikan khusus dan pendidikan layanan khusus di perguruan tinggi. [Special education and special service education in colleges].

Meyer, A. H., Myers, K. A., Walmsley, A. L., \& Laux, S. E. (2012). Academic accommodations: Perceptions, knowledge and awareness among college students without disabilities. Education, 2(5), 174-182. $\quad$ https://doi.org/10.5923/j. edu.20120205.10.

Meyers, S., \& Lester, D. (2016). An attempt to change college students' attitudes toward individuals with disabilities. Comprehensive Psychology, 5, 1-7.https:// doi.org/10.1177/2165222816648076.

Navarro-Mateu, D., Franco-Ochoa, J., ValeroMoreno, S., \& Prado-Gascó, V. (2020).
Attitudes, sentiments, and concerns about inclusive education of eeachers and teaching students in Spain. Frontiers in Psychology, 11, 1-11. https://doi. org/10.3389/fpsyg.2020.00521.

Nota, L., Santilli, S., Ginevra, M. C., \& Soresi, S. (2014). Employer attitudes towards the work inclusion of people with disability. Journal of Applied Research in Intellectual Disabilities, 27(6), 511-520. https://doi. org/10.1111/jar.12081.

Sahin, H., \& Akyol, A. D. (2010). Evaluation of nursing and medical students' attitudes towards people with disabilities. Journal of Clinical Nursing, 19(15-16), 22712279. $\quad$ https://doi.org/10.1111/j.13652702.2009.03088.x.

Sharma, U., Moore, D., \& Sonawane, S. (2009). Attitudes and concerns of pre-service teachers regarding inclusion of students with disabilities into regular schools in Pune,India.Asia-PacificJournalofTeacher Education, 37(3), 319-331. https://doi. org/10.1080/13598660903050328.

Sniatecki, J. L., Perry, H. B., \& Snell, L. H. (2015). Faculty attitudes and knowledge regarding college students with disabilities. Journal of Postsecondary Education \& Disability, 28(3), 259-275. https://www.ahead.org/ professional-resources/publications/jped/ archived-jped/jped-volume-28.

Szumski, G., Smogorzewska, J., \& Grygiel, P. (2020). Attitudes of students toward people with disabilities, moral identity and inclusive education-A two-level analysis. Research in Developmental Disabilities, 102, 1-12. https://doi. org/10.1016/j.ridd.2020.103685.

Tast, M. A. (2017). Exploring first-year college students' attitudes toward disability: Impacts of disability inclusion training (Thesis, St. Cloud State University). https://repository.stcloudstate.edu/cpcf etds $/ 35$.

UNESCO. (1994, 7-10 June). The Salamanca statement and framework for action on special needs education. World 
Conference on Special Needs Education: Access and Quality, Salamanca, Spain. https://www.european-agency.org/sites/ default/files/salamanca-statement-andframework.pdf.

Westbrook, M. T., Legge, V., \& Pennay, M. (1993). Attitudes towards disabilities in a multicultural society. Social Science \& Medicine, 36(5), 615-623. https://doi. org/10.1016/0277-9536(93)90058-C.

Westling, D. L., Kelley, K. R., Cain, B., \& Prohn, S. (2013). College students' attitudes about an inclusive postsecondary education program for individuals with intellectual disability. Education and Training in Autism and Developmental Disabilities, 48(3), 306-319. https://www.jstor.org/ stable/23880989.

Zhang, D., Landmark, L., Reber, A., Hsu, H. Y., Kwok, O.-M., \& Benz, M. (2010). University faculty knowledge, beliefs, and practices in providing reasonable accommodations to students with disabilities. Remedial and Special Education, 31(4), 276-286. https://doi. org/10.1177/0741932509338348. 
Appendix 1. Knowledge about Disabilities and Student Attitudes towards Inclusion Survey

No. Survey Item

\section{Knowledge about disabilities}

1. Saya tahu "disabilitas" berarti "gangguan fisik atau mental yang dapat menghambat satu atau lebih aktivitas kehidupan sehari-hari. (termasuk orang-orang yang pernah memiliki kebutuhan khusus, bahkan jika mereka saat ini tidak memiliki kebutuhan khusus. Mereka termasuk individu yang tidak memiliki kebutuhan khusus tetapi dianggap memiliki memiliki kebutuhan khusus)

2. Saya tahu UU RI nomor 8 tahun 2016 tentang penyandang disabilitas yang melarang diskriminasi terhadap individu penyandang disabilitas dan penerapannya bagi mahasiswa berkebutuhan khusus di lembaga-lembaga Pendidikan Tinggi.

3. Saya tahu Peraturan Menteri Riset, Teknologi, dan Pendidikan Tinggi Republik Indonesia nomor 46 tahun 2017 tentang pendidikan khusus dan pendidikan layanan khusus di perguruan tinggi, termasuk penerapannya bagi mahasiswa berkebutuhan khusus di institusi Pendidikan Tinggi.

4. Mahasiswa berkebutuhan khusus dapat belajar seperti teman sebaya mereka tanpa hambatan di tingkat perguruan tinggi.

5. Sekolah Tinggi / Universitas harus menyediakan kesempatan belajar dan akses kurikulum untuk mahasiswa berkebutuhan khusus.

6. Mahasiswa berkebutuhan khusus diizinkan untuk mengambil mata kuliah pengganti untuk mata kuliah tertentu yang disyaratkan atau prasyarat.

7. Mahasiswa berkebutuhan khusus diizinkan untuk mengurangi beban mata kuliah dan memperpanjang waktu untuk menyelesaikan persyaratan gelar.

8. Orang-orang dengan hambatan fisik memiliki kecerdasan yang sama dengan orang-orang pada umumnya.

9. Orang dengan disabilitas mudah bergaul dengan orang lain.

10. Disabilitas adalah kebutuhan khusus yang dapat dilihat secara fisik atau nyata.

\section{Student attitudes towards inclusion}

1. Hanya instruktur dengan pengalaman luas tentang pendidikan khusus yang dapat diharapkan berurusan dengan mahasiswa berkebutuhan khusus di lingkungan perguruan tinggi/universitas.

2. Perguruan tinggi/universitas dengan mahasiswa berkebutuhan khusus dan mahasiswa tidak berkebutuhan khusus dapat meningkatkan pengalaman belajar mahasiswa berkebutuhan khusus.

3. Mahasiswa berkebutuhan khusus terlalu lemah untuk mendapat manfaat dari kegiatan universitas.

4. Secara umum, mahasiswa berkebutuhan khusus harus ditempatkan di kelas/universitas khusus yang dirancang khusus untuk mereka.

5. Mahasiswa berkebutuhan khusus dapat memperoleh keuntungan dari berinteraksi dengan mahasiswa tidak berkebutuhan khusus.

6. Instruktur harus memiliki aspek inklusif yang memberdayakan semua mahasiswa untuk belajar dan berhasil secara adil terlepas dari kemampuan, latar belakang sosial, atau kemampuan sosial.

7. Instruktur harus merefleksikan secara hati-hati saat menyusun konten/isi mata kuliah yang inklusif untuk memenuhi kebutuhan mahasiswa yang beragam, termasuk mahasiswa berkebutuhan khusus.

8. Tidak adil meminta/mengharapkan instruktur untuk memasukkan mahasiswa berkebutuhan khusus di dalam kelas.

9. Sumber daya keuangan harus dialokasikan untuk integrasi mahasiswa berkebutuhan khusus.

10. Integrasi mahasiswa berkebutuhan khusus dalam program dan kegiatan pendidikan harus didorong dan diatur oleh kebijakan dan/atau undang-undang. 